\title{
Mare Geneticum: towards an Implementing Agreement for Marine Genetic Resources in International Waters
}

\author{
Thomas Vanagt, ${ }^{\mathrm{a}, \mathrm{b}}$ Arianna Broggiato, ${ }^{\mathrm{a}, \mathrm{b}}$ Laura E. Lallier, ${ }^{\mathrm{a}, \mathrm{e}}$ \\ Marcel Jaspars, ${ }^{\mathrm{c}}$ Geoff Burton, ${ }^{\mathrm{d}}$ and Dominic Muyldermans ${ }^{\mathrm{b}}$ \\ a eCOAST Marine Research, 8400 Ostend, Belgium \\ b ABs-int, $905^{2}$ Zwijnaarde, Belgium \\ c Marine Biodiscovery Centre, Department of Chemistry, University of \\ Aberdeen, Aberdeen AB24 3 UE, UK \\ d United Nations University, Institute for the Advanced Study of \\ Sustainability, Tokyo 150-8925, Japan \\ e Maritime Institute, Faculty of Law, University of Ghent, 9000 Ghent, \\ Belgium
}

\begin{abstract}
A fair and effective regime regulating benefit-sharing of marine genetic resources $(\mathrm{MGR})$ in areas beyond national jurisdiction $(\mathrm{ABNJ})$ must consider the inclusion of developing states, support scientific research and safeguard investments of the private sector. The present innovative proposal ensures a delicate balance through an approach based on open access, albeit with limitations. Access to MGR in ABNJ is facilitated, but conditional on the public release of collected samples and raw data. Adoption of the open access principle guarantees a powerful form of non-monetary benefit-sharing. The balance is maintained by the option for an extended embargo period, allowing samples and data to be kept confidential for a certain period, against payment to a biodiversity contribution fund. Monetary benefit-sharing, as a sector-negotiated percentage on revenue, could be imposed at the point of product commercialisation, and would offer a tangible payment system with a low transaction cost.
\end{abstract}

(C) THOMAS VANAgt, ARIANNA BROggiATo, LAURA E. LALliER, MARCEL JASPARS, GEOFF BURTON, AND DOMINIC MUYLDERMANS 2019 | DOI:10.1163/9789004391703_012

This is an open access chapter distributed under the terms of the prevailing CC-BY-NC license at the time of publication.

Geoff Burton, and Dominic Muyldermans - 9789004391703 


\section{Keywords}

marine genetic resources - areas beyond national jurisdiction - biodiversity - Law of the Sea - benefit-sharing - research - open access

\section{Introduction}

Mare Liberum.* Freedom of the seas. When Hugo Grotius wrote this pieceone of the foundations of contemporary maritime legal doctrine-in $1609,{ }^{1}$ the seas of this world had already been a de facto synonym for freedom for a number of centuries. In the context of naval conflicts in Europe, Grotius thought that the world's oceans should be freely accessible to all and shared amongst nations. This perspective was in direct response to the Portuguese maritime policy that claimed exclusivity of traffic to the East Indies for trade purposes. ${ }^{2}$ Grotius's essay was not well received then. A further example of opposition to the freedom of the seas was provided by John Selden's Mare Clausum. This gives insight into the British point of view at the time, claiming a monopoly over fishing rights in the North Sea. ${ }^{3}$

Nevertheless, Grotius's Mare Liberum left us with a heritage of thoughts tending towards the consideration of the oceans as a common space and common resource to be "free and open to all". ${ }^{4}$ Even though coastal states' creeping

* This chapter is an updated version of Broggiato, A., Vanagt, T., Lallier, L.E., Jaspars, M., Burton, G. and Muyldermans, D. Mare Geneticum: Balancing Governance of Marine Genetic Resources in International Waters. International Journal of Marine and Coastal Law vol. 3 issue 1 Pages 3-33 (2017).

Corresponding author: Thomas Vanagt (e-mail: thomas.vanagt@abs-int.eu). Arianna Broggiato and Thomas Vanagt are equally contributing first authors. Acknowledgements: This chapter is a background contribution to the PharmaSea project-Increasing Value and Flow in the Marine Biodiscovery Pipeline-supported by the European Union's FP7 Programme under grant agreement No 312184. The authors would like to thank Lyle Glowka, Meredith Evans-Lloyd, Matthias-Leonhard Mayer, Chris Lyal, Hiroko Muraki Gottlieb, Julian Jacksons and the referees for their comments on a preliminary draft of their article. Any comments expressed by the authors therein must not be attributed to any state, international body or non-governmental organization.

1 H Grotius, Freedom of the Seas, or, the right which belongs to the Dutch to take part in the East Indian trade (Oxford University Press, New York, 1916).

2 MB Vieira, 'Mare Liberum vs. Mare Clausum: Grotius, Freitas, and Selden's debate on dominion over the seas' (2003) 64(3) Journal of the History of Ideas 361-377, at p. 361.

3 Ibid., at p. 362 .

4 H Grotius (n 1), at p. 32 . 
jurisdiction has continuously expanded into the ocean over the 2oth century, ${ }^{5}$ $40 \%{ }^{6}$ of the planet's surface ( $64 \%$ of the surface of the oceans) still lies in international areas of the High Seas ${ }^{7}$ and the Area, ${ }^{8}$ commonly referred to as areas beyond national jurisdiction (ABNJ).

The Freedom of the High Seas that all sailors knew and cherished slowly became a "relative" freedom as the international community cooperated to regulate certain activities that occur in ABNJ. The 1958 Geneva Convention on the High Seas ${ }^{9}$ addresses what can and cannot be controlled in international waters, e.g., piracy, pollution, and the activity of warships.

In 1982, with the adoption of the United Nations Convention on the Law of the Sea (LOSC), ${ }^{10}$ the jurisdiction of coastal states was further extended. The freedom of the High Seas, though recognised as a principle, was further restricted. In the Area, for example, mineral resources were designated as being the Common Heritage of Mankind. ${ }^{11}$

Despite appearances, however, Grotius's heritage has not been slowly erased but rather operationalized. The pillar of his argument for freedom relied on the idea of sharing a common domain: the sea. ${ }^{12}$ The current tendency to regulate these traditionally unregulated areas is not occurring in a Mare Clausum type of policy, but is rather following the recognition that there is a further need for sharing the resources provided by our planet. This comes with realising the need for international cooperation and regulation in order to put the adequate frameworks in place within which such sharing can happen in a peaceful and harmonised way.

In the context of this ideology of global sharing, the international community is now in the process of negotiating a new international legally binding instrument (ILBI) under the LOSC. Launched by the UN General Assembly in $2004,{ }^{13}$ the purpose of the "biodiversity beyond national jurisdiction"

E Franckx, "The 200-Mile Limit: Between Creeping Jurisdiction and Creeping Common Heritage? Some Law of the Sea Considerations from Professor Louis Sohn's Former LL.M. Student' (2007) 39(3) The George Washington International Law Review 467-498, at p. 469 et seq.

See the Global Environment Facility, available at http://www.thegef.org/topics/areas -beyond-national-jurisdiction; accessed 18 January 2017. United Nations Convention on the Law of the Sea (Montego Bay, 10 December 1982, in force 16 November 1994), 1833 UNTS 396, Art. 87.

$8 \quad$ Ibid., Art. 1(1).

9 Convention on the High Seas (Geneva, 29 April 1958, in force 30 September 1962), $45^{0}$ UNTS 11 .

$10 \quad \operatorname{LOSC}\left(\mathrm{n}_{7}\right)$.

11 Ibid., Art. 136.

12 Grotius ( $\mathrm{n} 1)$, at p. 22 et seq.

13 UNGA Res. 59/24, UN Doc. A/RES/59/24, 17 November 2004, para. 73. 
(BBNJ) process was to assess the status of conservation and sustainable use of marine biodiversity in ABNJ and to investigate the potential need for further international cooperation. The BвNJ process led the General Assembly to launch the development of the aforementioned ILBI in 2015, establishing a Preparatory Committee for the purpose of providing recommendations on the elaboration of a draft text. ${ }^{14}$ The Preparatory Committee "shall address the conservation and sustainable use of marine biological diversity of areas beyond national jurisdiction, in particular, together and as a whole, marine genetic resources, including questions on the sharing of benefits [...]". ${ }^{15}$ In July 2017, at the end of the fourth meeting of the Preparatory Committee, a recommendation to the UN General Assembly was adopted by consensus, even though many items remain unresolved, amongst other many aspects related to marine genetic resources (MGR), including the sharing of benefits. ${ }^{16}$ On December 24 , 2017, the UN General Assembly adopted by consensus Resolution $72 / 249^{17}$, to convene an intergovernmental conference and undertake formal negotiations for a new international legally binding instrument under the LOSC for the conservation and sustainable development of marine biological diversity in areas beyond national jurisdiction. The organizational meeting for the intergovernmental conference took place from 16-18 April 2018.

When considering the issue of MGR and the sharing of benefits in this вв NJ context, the international community has come a long way from Hugo Grotius's conception-but not that long. Grotius had a spatial approach to the freedom of the seas, arguing that access and navigation was the right of all for "the sea is common to all". 18 The international community has moved from sharing the ocean space freely to sharing its natural resources in an organised and regulated fashion, in particular commodities like fish and minerals.

Centuries later, the вBNJ process is now trying to govern and regulate the less tangible but nevertheless valuable biodiversity, with the aim of enhancing

\footnotetext{
14 UNGA Res. 69/292, UN Doc. A/Res/69.292, 6 July 2015, para. 1(a).

15 Ibid., para. 2.

16 Report of the Preparatory Committee established by General Assembly Resolution 69/292: Development of an international legally binding instrument under the United Nations Convention on the Law of the Sea on the conservation and sustainable use of marine biological diversity of areas beyond national jurisdiction, UN Doc. A/AC.287/2017/ PC.4/2, 21 July 2017, p.20. Available at www.un.org/ga/search/view_doc.asp?symbol=A/ AC.287/2017/PC.4/2; accessed 30 October 2017.

17 Resolution 72/249 adopted by the General Assembly on 24 December 2017. International legally binding instrument under the United Nations Convention on the Law of the Sea on the conservation and sustainable use of marine biological diversity of areas beyond national jurisdiction. Available at https://undocs.org/en/A/RES/72/249; accessed June 2018.

Grotius (n 1), at p. 28.
} 
access for scientific research on MGR in ABNJ and for the sharing of benefits arising from their utilisation. ${ }^{19}$ This enhanced access to MGR cannot be regarded independently from the overarching objectives of sustainable use and conservation of marine biodiversity in ABNJ. In its modern and evolved version, the Mare Liberum of the 17th century thus finds its echo in the Mare Geneticum of the 21st century.

In recent years, many comprehensive scholarly studies have been written on the topic of MGR in ABNJ, analysing international cooperation issues, identifying legal gaps and illustrating possible interpretations. Hence, the present article will not introduce the history and diplomacy behind the вв $\mathrm{NJ}$ process, ${ }^{20}$ neither will it analyse in depth the legal issues raised by a new treaty surrounding the discussion. Enshrined in the Mare Geneticum approach of shared access and utilisation, this article provides a pragmatic approach to the MGR in ABNJ component of the new ILBI, aiming to inform and inspire the BBNJ negotiations. The analysis will cover all three pillars of an access and benefit-sharing (ABS) regime: access; benefit-sharing; and compliance.

This article first gives an overview of the building blocks of the proposed governance regime. It then lays out the scientific and technical foundations forming the rationale of our proposal. This includes findings based on recent technical analyses on the market value of MG R in ABNJ and the gaps in research capabilities of states, and indications where relevant data are not available and further studies might be needed.

The core of this article further develops each building block of the proposed governance regime for MGR in ABNJ. This is followed by an illustration of how the scientific community implements in practice the concept of open access to data and samples as applicable to marine scientific research (MSR) in ABNJ, as we propose in this article. The final section illustrates a potential centralised compliance system, before summing up the whole proposed governance regime.

19 For a comprehensive description of access to MGR within national jurisdiction of coastal States, see LE Lallier, O McMeel, T Greiber, T Vanagt, AD Dobson and M Jaspars, 'Access to and use of marine genetic resources: understanding the legal framework' (2014) 31(5) Natural Products Reports 612-616; LE Lallier, A Broggiato, D Muyldermans and T Vanagt, 'Marine Genetic Resources and the Access and Benefit-Sharing Legal Framework' in LJ Stal and MS Cretoiu (eds.), The Marine Microbiome-An Untapped Source of Biodiversity and Biotechnological Potential (Springer International Publishing, Switzerland, 2016) 453-472.

20 A Broggiato, S Arnaud-Haond, C Chiarolla, and T Greiber, 'Fair and equitable sharing of benefits from the utilization of marine genetic resources in areas beyond national jurisdiction: Bridging the gaps between science and policy' (2014) 49 Marine Policy 176-185, at pp. 179-181. 
The proposed governance regime can be divided into three steps that build on the СвD and its Nagoya Protocol: access, benefit-sharing and compliance. However, it is not the ambition or purpose of this article to provide detailed or final solutions, in particular with regard to enforcement or implementation measures. Rather, Mare Geneticum seeks to propose sound basic principles for the establishment of a realistic and functioning MGR regime in ABNJ. The principles are visualised in Fig. 1.

In this regime, in situ access to MGR in ABNJ is facilitated through a simple notification step: the Obligatory Prior Electronic Notification (OPEN). The online notifications submitted by (prospective) users should be managed by the international organisation that will likely be established or mandated by the ILBI. However, the user must accept certain conditions for the OPEN to be recorded: the obligation to share non-monetary and monetary (when applicable) benefits arising from the utilisation of the MGR. The OPEN is the starting point of a track-and-trace system that can benefit both the users and the regulator.

The main non-monetary benefit is based on the open access $(\mathrm{OA})$ principle: releasing samples and raw data (metadata and, if applicable, genetic sequence data and biochemical data) to the public domain through openly accessible biorepositories and databases. Connecting various collections around the globe will strengthen existing and newly created networks of biorepositories, or "common pools" of MGR. ${ }^{21}$ Their coordination, coupled with the OA approach, will therefore facilitate $e x$ situ access as easily as in situ sampling through the same OPEN system.

To safeguard the interests of scientists and of commercial users, limitations to the OA principle can be awarded via an embargo period which will allow a user to keep material and data private for a certain period, e.g., to secure confidentiality while publishing the first results of research or while applying for a patent. When needed, the embargo could be extended, triggering the payment of an exclusivity fee as a counterpart. This will allow users to further

21 Broggiato et al. (n 20), at p. 181; T Greiber, 'Common pools for marine genetic resources: a possible instrument for a future multilateral agreement addressing marine biodiversity in areas beyond national jurisdiction', in EC Kamau and G Winter (eds.), Common Pools of Genetic Resources - Equity and Innovation in International Biodiversity Law (Routledge, London and New York, 2013), 399-414, at pp. 407-411; G Wright, J Rochette and T Greiber, 'Sustainable Development of the Oceans: Closing the Gaps in the International Legal Framework' in V Mauerhofer (ed.), Legal Aspects of Sustainable Development (Springer International Publishing, Switzerland, 2016) 549-564, at p. 556. 


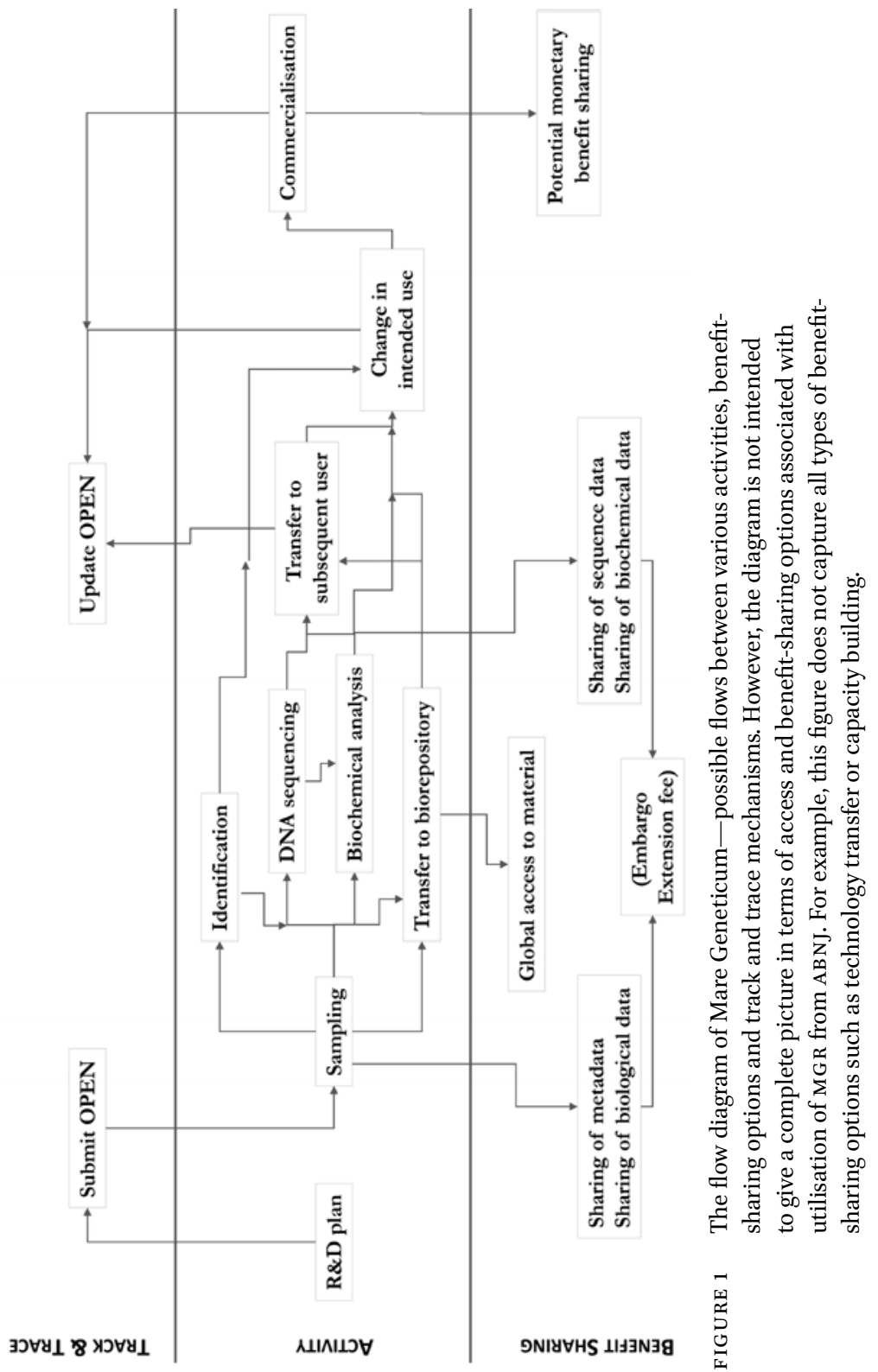


advance their research and to safeguard their investments. The exclusivity payments could be made into a biodiversity contribution fund. Such a fund should be dedicated to the functioning of an international organisation, if any is to be mandated by the ILBI, for the regular implementation and management of the relevant MGR provisions, as well as to contribute to the conservation efforts of the three other building blocks of the BBNJ package, namely environmental impact assessments, marine protected areas and technology transfer. The Mare Geneticum approach thus offers three possibilities to users:

- Open Access to MGR and data;

- Embargo period (relatively short);

- Exclusivity subject to payment.

If monetary benefits, additional to the exclusivity fee, would be agreed upon during the negotiation of the ILBI, we suggest these to be linked to the commercialisation of a product derived from MGR coming from $\mathrm{ABNJ}$, and not to the act of research and development (R\&D) itself. In this case to reduce the transaction cost and to maximize predictability, which are necessary to attract investments from the private sector, a fixed percentage would be preferable over case-by-case negotiations.

Compliance will be ensured through the centralised system of the OPEN registry whereby reports and additional conditions arising during the lifespan of MGR and data utilisation will be kept and tied to it, enabling easy tracking and tracing.

\section{3}

\section{Rationale for Mare Geneticum}

\subsection{Premises}

The premises of the present proposal are based on the need for a multilateral system to regulate MGR from ABNJ and the importance of sustaining scientific research undertaken by both public and private users. This article acknowledges that ensuring the sustainable use of MGR from $\mathrm{ABNJ}$ together with the fair and equitable sharing of the benefits arising from their utilisation is possible only by bridging the gap between those countries that hold knowledge, MGR and technologies, and those that do not, ${ }^{22}$ in order to achieve a more "[...] equitable and efficient utilisation of their (seas and oceans) resources" as stated in the fourth paragraph of the Preamble to the Losc.

Given the absence of national jurisdiction in the geographical area concerned, any regime regulating ABS of MGR needs to be multilateral in order to 
be effective. Moreover, access should be granted upon pre-defined conditions, as a case-by-case negotiation of terms would increase the costs, lengthen the administrative procedure and, most importantly, impair legal certainty for the users. The ILBI must provide legal certainty and stability both for the scientific community and for the private sector. Indeed, being able to assess (financial) risks at the onset of $R \& D$ would provide companies with the stable environment in which they can make the necessary investments.

A multilateral approach also ensures consistency by not differentiating between the water column (High Seas) and the seabed (Area) in ABNJ as neither science nor the definition of MGR justifies such a differentiation. ${ }^{23}$ Support for this overarching approach lies in the UN General Assembly Decision on the development of an ILBI, which, as well as requiring action under the framework of the LOSC, specifically decides that the question of MGR be addressed "together and as a whole"24

MSR is crucial to advance knowledge of the marine environment, which includes, e.g., marine biodiversity, ecology and ecosystem processes, and for its role in the provision of ecosystem services and the maintenance of ocean health for the benefit of not only humankind but also the planet. Advancing our knowledge of the marine environment brings many environmental, social and economic benefits, ${ }^{25}$ by, e.g., contributing to food security, conserving and managing the marine environment and resources, helping to understand, predict and respond to natural events and to human impacts and processes, eradicating poverty and contributing to sustainable development. ${ }^{26}$ In addition, scientific research on MGR may lead to applications in biotechnology. Therefore, the strategic purpose of an ILBI should be to promote MSR and further downstream research directed to advancing scientific knowledge and understanding of the oceans for the wider long-term benefit of the world. ${ }^{27}$

23 Conservation and Sustainable Use of Marine Biological Diversity of Areas beyond National Jurisdiction: Preparing for the PrepCom, Report of the BвNJ Workshop of the Centre for International Law, National University of Singapore, February 2016, available at http://cil.nus.edu.sg/wp/wp-content/uploads/2015/10/CIL-report-of-BBNJ-workshop -21-March-2016-final-2.pdf; accessed 18 January 2017.

24 UNGA Res. 69/292 (n 14), para. 2.

25 H Harden-Davies, 'The regulation of marine scientific research: addressing challenges, advancing knowledge' in RM Warner and SB Kaye (eds.), Routledge Handbook of Maritime Regulation and Enforcement (Routledge, Abingdon, 2016) 212-230, at p. 216.

26 UN Report of the Secretary-General UNGAOR, UN Doc. A/64/66/Add.2, 19 October 2009, para. 15 .

27 Harden-Davies (n 25), at p. 228; P Oldham, S Hall, C Barnes, C Oldham, AM Cutter, N Burns, and L Kindness, 'Valuing the Deep: Marine Genetic Resources in Areas Beyond National Jurisdiction' (Defra, London, 2014) 1-241, at p. 18. 
Advances in science require the availability of research material, samples and data, together with advanced technologies and research capabilities. To facilitate access to MGR in ABNJ, the governance mechanism should be based on a principle of $\mathrm{OA}$ by coupling light-touch procedures with the obligation to share the raw data and to deposit samples in publicly accessible biorepositories (see infra). OA refers to research outputs that are free of all restrictions on access (e.g., access tolls). However, it does not necessarily mean free utilisation, as some restrictions or conditions of use may be attached to the accessed material or data. For example, some databases of images available online currently associate certain copyright and license restrictions on the use of such images (e.g., forbidden sales, limited modifications...), without restricting access as such.

To ensure that regulations arising out of ILBI are not overly burdensome or inapplicable in practice, ${ }^{28}$ an excellent understanding of the MSR process is an absolute necessity. The involvement of the marine scientific community is therefore of paramount importance: we echo the need to bridge the gaps between science and policy. ${ }^{29}$

\subsection{Scientific and Technical Baseline \\ 3.2.1 Commercial Value of MGR in ABNJ}

Prior to discussing potential benefit-sharing arrangements related to MGR in ABNJ, their actual commercial value should be assessed. Are the expectations of large financial gains from the utilisation of MGR in ABNJ realistic?

Uncertainty has been raised about the actual likelihood of commercialisation following R\&D on MGR, ${ }^{30}$ and too much emphasis has generally been placed on monetary benefitstreams. Indeed, there is currently little evidence of

28 A Broggiato, 'Exchange of information on research programs regarding marine biodiversity in areas beyond national jurisdiction' in IUCN information papers for the intersessional workshop on marine genetic resources in ABNJ (IUCN Environmental Law Center, Bonn, 2013) 55-62, at p. 55; Harden-Davies (n 25), at p. 218. Available at http://www .un.org/depts/los/biodiversityworkinggroup/documents/IUCN\%2oInformation\%20 Papers\%2ofor\%2oBBNJ\%2oIntersessional\%2oWorkshop\%20on\%2oMGR.pdf; accessed 18 January 2017.

29 Broggiato et al. (n 20), at p. 176.

3o DK Leary and SK Juniper, 'Addressing the marine genetic resources issue: Is the debate heading in the wrong direction?' in C Schofield, S Lee and MS Kwon (eds) The Limits of Maritime Jurisdiction (Martinus Nijhoff Publishers, Leiden, 2014) 769-785, at p. 773; and D Leary, M Vierros, G Hamon, S Arico, and C Monagle, 'Marine Genetic Resources: A Review of Scientific and Commercial Interest' (2009) 33 Marine Policy 183-194, at p. 187. 
systematic commercial-scale development of MGR from ABNJ. ${ }^{31}$ Furthermore, it is important not to confuse the potential of MGR in ABNJ with the more prolific commercialisation of marine biodiversity products from shallower waters, primarily within coastal states' jurisdiction. ${ }^{32}$ In theory, marine biodiversity has enormous potential. Biochemists are often effusively enthusiastic about the diversity of biomolecules produced by marine organisms compared to their terrestrial counterparts. However, to date, the realisation of this potential in relation to $\mathrm{ABNJ}$ has been slow compared to national jurisdictions. ${ }^{33}$ Therefore, although the potential for development has been widely stated, ${ }^{34}$ its appreciation still requires further study. Moreover, a comprehensive study reviewing the full spectrum of monetary and non-monetary benefits that could be derived from MGR in ABNJ would also be invaluable, as there appears to be none at this stage. ${ }^{35}$

At present, there are a number of patents and pending applications based on MGR in ABNJ, both from the Area and the high seas. This can be interpreted as evidence for commercial interest. ${ }^{36}$ However, the existence of such patents does not necessarily indicate the eventual development of marketable products. Moreover, there is increasing evidence of academia seeking patents to protect their intellectual property (IP), even without true commercial intent.

Finally, distinguishing new MGR discoveries within national jurisdictions from those in ABNJ should be encouraged in a more systematic manner. To this end, the UnEsco Intergovernmental Oceanographic Commission added the option "areas beyond national jurisdiction" for geographical search in the new version of the Ocean Biogeographic Information System (овIs) platform. овIS is a global data-sharing platform and clearing house for marine biodiversity (biogeographic and biometric) data in all oceans, hosted by the International Oceanographic Data and Information Exchange (IODE). Marinlit, the Royal

31 Leary and Juniper (n 30), at p. 773; SK Juniper, 'Technological, Environmental, Social and Economic Aspects of Marine Genetic Resources' in IUCN information papers for the intersessional workshop on marine genetic resources in ABNJ (IUCN Environmental Law Center, Bonn, 2013) 15-21, at pp. 20-21.

32 Oldham et al. (n 27), at p. 197.

33 Juniper (n 31$)$, at p. 19.

34 Ibid.; Oldham et al. (n 27), at p. 182.

35 L Glowka, 'Evolving Perspectives on the International Seabed Area's Genetic Resources: Fifteen Years after the Deepest of Ironies' in D Vidas (ed.), Law, Technology and Science for Oceans in Globalisation (Martinus Nijhoff Publishers, Leiden, 2010) 397-419, at p. 415.

36 M Vierros, C Salpin, C Chiarolla and SM Arico, 'Emerging and unresolved issues: The example of seabed and open ocean genetic resources in areas beyond national jurisdiction' in SM Arico (ed.), Ocean sustainability in the 21st century (Cambridge University Press, Cambridge, 2015) 198-232, at p. 212. 
Society of Chemistry database, is also of interest as it gives the location, when available, of organisms from which compounds were derived, clearly showing that most are derived from the Exclusive Economic Zone (EEZ). ${ }^{37}$

\subsubsection{Gaps in Research Capabilities of States}

In order to propose the most widely acceptable options for the ILBI governance system, it is necessary to identify the areas where inequalities between states are most pronounced. The analysis should focus on the actual availability of MGR from ABNJ and the capacities needed to study and exploit them..$^{38}$ Genetic resources can be accessed in different ways: in situ, ex situ, and in silico. Access to in-situ resources means collecting samples of marine organisms (containing genetic material) within their natural surroundings. Access to ex situ MGR occurs when the resources are accessed away from their natural surroundings, such as from culture collections, museums and research institutions. In silico normally describes direct access to genetic data, such as whole genomes or isolated gene sequences, with or without functional annotations, or biochemical data on gene products, such as proteins, peptides and metabolites.

Recent technical analyses showed uneven levels of access to MGR between a small group of developed countries and the rest of the world, mostly for the following reasons:

1. The cost of technology to sample in international waters and the deep sea, and the cost of its maintenance; ${ }^{39}$

2. The scientific skills needed to undertake research on marine biodiversity; 40

3. The cost of and scientific skills needed to undertake molecular screening and biodiversity assessment; ${ }^{41}$

4. The scientific skills needed to analyse the data thereby produced. ${ }^{42}$

37 MarinLit is a database dedicated to marine natural products research. http://pubs.rsc. org/marinlit/.

$38 \quad$ Glowka (n 35), at pp. 411-412.

39 Broggiato et al. (n 20), at p. 177; Juniper (n 31), at pp. 15-17; K Juniper, 'Use of Marine Genetic Resources' in M Banks, C Bissada, PE Araghi (eds), The First Global Integrated Marine Assessment World Ocean Assessment I under the auspices of the United Nations General Assembly and its Regular Process for Global Reporting and Assessment of the State of the Marine Environment, including Socioeconomic Aspects (UN, New York, 2016), Chapter 29, at p. 6.

$40 \quad$ Juniper (n 39), at p. 9; Juniper (n 31), at pp. 16-17.

41 Broggiato et al. (n 20), at p. 179.

42 Juniper (n 39), at p. 7; G Shimmield, 'Extent and Types of Research, Uses and Applications' in IUCN information papers for the intersessional workshop on marine genetic resources in $A B N J$ (IUCN Environmental Law Center, Bonn, 2013), 7-15, at p. 13. 
In 1995, only six countries had the technological, financial and human resources to directly access MGR in situ in ABNJ (Finland, France, the United Kingdom, Japan, Russia and the United States of America). ${ }^{43}$ In 2012, twenty-nine countries, both developed and developing, had access to MGR from hydrothermal vents, as members of InterRidge, (an organization for International Cooperation in Ridge-Crest Studies), ${ }^{44}$ and of the Pacific Islands Applied Geoscience Commission. ${ }^{45}$ However, notwithstanding the wider access to deep-sea sampling technologies, disparity remains. ${ }^{46}$

Another important capability to derive value from marine biodiversity is the specialist scientific skills required to identify species, both those species that are already known and those that are new to science. ${ }^{47}$ These taxonomic specialists are mostly trained in developed countries with a long history of botanical and zoological scholarship in universities and museums. A recent review of the literature revealed that the majority of publications in the field of marine taxonomy come from relatively few developed countries. ${ }^{48}$ These specialists are experts in the morphological identification of specimens (classical taxonomy) and, increasingly, the interpretation of DNA sequence information to identify marine plants, animals and microbes (molecular taxonomy). There is a global scarcity of taxonomists able to identify marine flora and fauna. This problem is particularly acute for a range of marine invertebrate phyla. ${ }^{49}$

Various scientific approaches to undertake molecular screening and analyse the acquired data, such as microbial metagenomics, also require sophisticated bioinformatics tools and training which are most accessible in developed countries. ${ }^{50}$ Nevertheless, some capabilities in bioinformatics and genomics exist in developing countries, particularly in the health and agricultural science sectors, and these skills could be adapted and applied for use in the context of MGR. ${ }^{51}$ Moreover, there are capacity-building initiatives aimed at lowering this disparity. The UK's Wellcome Trust, for example, provides training in genetic data analysis (mainly on human genome and human pathogens) to developing countries, as does Japan's National Institute of Technology and Evaluation.

\footnotetext{
43 Glowka (n 35), at p. 412.

44 Available at www.interridge.org; accessed 18 January 2017.

45 Glowka (n 33), at p. 412.

46 Broggiato et al. (n 20), at p. 179; Juniper (n 31) at p. 15-16; Juniper (n 39), at p. 6.

47 IE Hendriks and CM Duarte, 'Allocation of effort and imbalances in biodiversity research' (2008) 360(1) Journal of Experimental Marine Biology and Ecology 15-20, at p. 17; Juniper (n 39), at p. 7 .

$48 \quad$ Ibid. Hendriks and Duarte, at p. 18.

49 Available at www.publications.parliament.uk/pa/ld200708/ldselect/ldsctech/162/162.pdf; accessed 18 January 2017.

5o Juniper (n 39), at p. 8; Shimmield (n 42), at p. 13 .

51 Juniper (n 31), at p. 17; Juniper (n 39), at p. 8; Shimmield (n 42), at p. 17.
} 
Technological advances are now radically changing life sciences: ${ }^{2}$ the cost of sequencing has decreased significantly and new technologies have emerged, such as bioinformatics. OA bioinformatics databases are essential for the success of genetics as they enable the discovery of new genes unexplored by the depositor of the data and their comparison to large sets of genes and sequences deposited by others in the databases. The ability to mine public domain and $\mathrm{OA}$ databases containing genomic and proteomic data, and to subsequently use such data, could become as important as physical access to organisms or their genetic material. ${ }^{53}$ This practice has led the genetics community to enthusiastically adopt the OA database model (see infra). As Glowka points out, "in theory, all that would be needed is internet access, appropriate software and skilled researchers", 54 allowing further engagement of developing countries' scientists.

To sum up, as underlined by the First Assessment of the Ocean made by the United Nations, the current uneven research capabilities across the globe are the primary source of inequity amongst states, ${ }^{55}$ more than disparities in accessing the resources in situ (authors' emphasis). This requires efforts in capacity development related to MSR so that a greater number of countries can participate in the exploitation of MGR. ${ }^{56}$ Therefore, after ensuring OA to samples and data as one of the main ways of benefit-sharing (see infra), the ILBI should promote and strengthen capacity building.

Mare Geneticum: Balancing Open Access and Commercial Interests

\subsection{Facilitated but Conditional Access}

The UNGA Resolution defines the subject of the ILBI negotiation in the 2011 package as "the conservation and sustainable use of marine biological diversity of $\mathrm{ABNJ}$, in particular, together and as a whole, marine genetic resources, including questions on the sharing of benefits..." ${ }^{n 7}$ without specifically mentioning the question of access to MGR. Notwithstanding the fact that access is a prerequisite to enforce subsequent benefit-sharing, Mare Geneticum proposes that the facilitated access procedure should be subject to notification rather than authorisation.

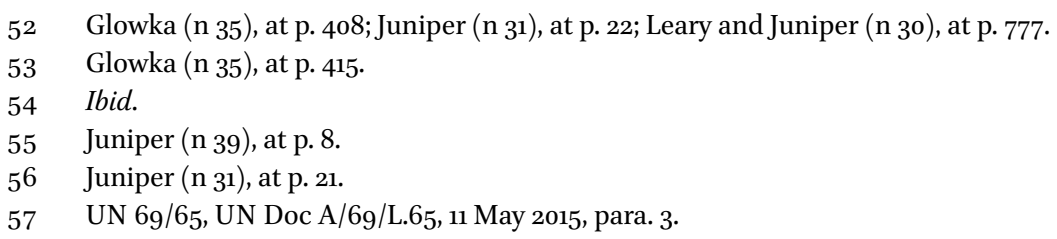


In situ access to M GR is generally done without commercial intent. ${ }^{58}$ Indeed, most deep-sea and high-seas expeditions are publicly funded, rendering MGR sampling cruises in $\mathrm{ABNJ}$ non-commercial in character, or at least with intentions that are not solely or primarily commercial. ${ }^{59}$ Moreover, most publicly funded institutions require the deposit of taxonomic and genetic discoveries in public collections and databases, usually within one year of the completion of a project. It should be noted, however, that extracts of marine samples collected for non-commercial purposes might be deposited in collections with a drug discovery objective, or be subsequently used for R\&D purposes. Indeed, the majority of biodiscovery ventures with a commercial interest begin with ex situ or in silico access rather than in situ.

As strongly advocated by the scientific community, ${ }^{60}$ in designing and implementing any ABS measures for MGR in ABNJ it is important to avoid excessive bureaucratic burdens that could hamper MSR. Within the present proposal, all the different ways to access MGR coming from ABNJ are facilitated.

\subsection{1}

Notification Procedure: Obligatory Prior Electronic Notification (OPEN)

The facilitated procedure to access MGR from ABNJ in situ consists of an Obligatory Prior Electronic Notification (OPEN) step, submitted electronically via a registration platform that will be publicly accessible in an online registry. The OPEN will require a minimum dataset of information to be recorded: it is important to underline that most of these data are already collected by scientists and there will be no extra burden on them. The dataset includes:

- Information about the collector and the corresponding contact point;

- Geographical area(s) of sampling;

- Period of sampling;

- Complete description of the research project and participating research entities. This may be based on the cruise plan that is often provided with funding applications;

$5^{8} \quad$ Juniper (n 31$)$, at p. 18.

59 Wright et al. (n 21), at p. 557.

6o Deep-sea marine scientific research and genetic resources in areas beyond national jurisdiction: Dosi submission to the Second Preparatory Committee—22 March 2016. Deep Ocean Stewardship Initiative (DOSI) is a union of experts from across disciplines and sectors formed to develop new ideas for sustainable use and management of deep-ocean resources. Available at www.un.org/depts/los/biodiversity/prepcom_files/DOSI.pdf; accessed 30 October 2017. 
- Expected nature of what will be collected - this should be done by sample type, for instance: pelagic vertebrate, benthic invertebrate, sediment, core sample, plankton, water, etc.;

- Description of the targeted MGR when possible; The dataset to fill in will be accompanied by a click-wrap agreement to be signed, including the commitments:

- The commitment to release the collected samples or data in an openly accessible biorepository, with or without exceptional conditions depending on the intent of use (see infra);

- The commitment to update the OPEN information at certain milestones. This is critical to ensure compliance and monitoring.

Any OPEN will contain OA conditions and benefit-sharing obligations associated with the collected material, whether those are monetary or not. The lifetime of the samples and extracted data will be punctuated with milestones corresponding to the identification of samples, to the deposit of samples and/ or duplicates in a collection, and to the transfer to users and change of intent for utilisation, as will be defined in the ILBI and for which any agreement on conditions of utilisation and benefit-sharing should be linked or annexed to the OPEN. It is advisable to link the OPEN platform to the СвD Clearing House database, ${ }^{61}$ in order to ensure that all genetic resources accessed in ABNJ are recorded in the СвD Clearing House, therefore avoiding free riders.

A unique alphanumeric identifier will be associated with each OPEN and will keep track of the cruise information and the samples collected. Each code associated with these samples throughout their lifetime should reflect this identifier, allowing subsequent determination of the provenance and hence securing legal certainty and compliance (see infra). This is needed to harmonise MSR practice and will generate a valuable database on global marine biodiversity.

A chosen institution should manage the secure internet tool capable of collecting this information through a centralised mechanism, or coordinate a decentralised system. Whether a new organisation is established by the ILBI or whether an existing institution is mandated for this purpose will have to be determined by the international community's negotiations on the ILBI terms.

When MGR from ABNJ are accessed ex situ in a collection, a notification should be registered on the same online registry and linked to the existing OPEN, which may be amended with additional information or conditions of utilisation. In case of commercial intent, the user will be required to accept

61 Available at https://absch.cbd.int/; accessed 18 January 2017. 
and be bound by possible monetary benefit-sharing obligations in addition to the already existing non-monetary benefits, entailing a subsequent payment to the biodiversity contribution fund upon commercialisation of any product as described further below, if agreed in the ILBI. These conditions can be easily encoded into the material transfer agreement signed with the collections in order to gain access to and use the requested MGR. This material transfer agreement should then be annexed to the OPEN to ensure traceability. As such, the OPEN travels with the material from one user to the next user, with the obligation for each user to keep the OPEN up to date.

In cases of in silico access a notification in the OPEN registry should be completed once the geographical origin of the MGR generating the data is known. Access to in silico data is quite challenging to track and trace, as is shown by the examples occurring within national jurisdictions under the CBD and Nagoya Protocol system. The Global Catalogue of Microorganisms (GCM), ${ }^{62}$ a global OA bioinformatics database, is working on ensuring ABS compliance by means of linking the unique identifier of each strain of microorganism to the internationally recognized certificate of compliance (IRCC) ${ }^{63}$ of the CBD Clearing House. The GCM provides authenticated access and material information and could accommodate all OPEN data or Nagoya Protocol IRCC. The GCM software uses the submitted strain identifiers to search for published patent records for the same identifiers and can provide reports on these. Therefore, the GCM software potentially allows anyone to trace any use of the material and identify any patents taken out or licenses granted under patent, contributing to the provision of legal certainty. The requirement to include the OPEN identifier in any record or publication could enable the system to run automatic searches and accrue records, as is being done by the GCM to some extent.

62 WFCC Global Catalogue of Microorganisms (GCM) is a system to help culture collections to manage, disseminate and share the information related to their holdings. http://gcm .wfcc.info/ Accessed 17 March 2017.

63 The internationally recognized certificate of compliance (IRCC) originates from the permit or its equivalent issued by State Parties to the Nagoya Protocol at the time of access as evidence that access to genetic resources was based on prior informed consent and that mutually agreed terms were established. When the permit is communicated to the ABS Clearing house of the Nagoya Protocol it becomes the IRcc. 
In the field of in silico access, GenBank ${ }^{64}$ operates under the INSDC policy, ${ }^{65}$ which advocates full $\mathrm{OA}$ and prohibits restrictions or licensing requirements. Nevertheless, Mare Geneticum's approach includes exceptions that will allow future commercial ventures and investments that would be discouraged. The ABS compliance with INSDC in linking gene sequences with eventual ABS strings attached might become an issue of discussion within the framework of the Nagoya Protocol. In this case, if compliance can be ensured with the collaboration of the INSDC, a similar project to the one run between the GCM and the ABs $\mathrm{CH}$ could be operated between GenBank and the СвD Clearing House in order to link the sequence data to the original material, its ABs conditions and to the OPEN registry. This would enable users to easily be aware of their obligation to share the benefits when utilizing sequence data of MGR from ABNJ.

\subsubsection{Authorisation Procedure in the Case of Environmental Impact}

Assessment

Sampling at sea does not usually produce significant environmental disturbance, therefore no environmental impact assessment (EIA) should be required prior to the activity. However, there should be a screening stage that could trigger the need for EIA, for instance when sampling will occur in marine protected areas or in vulnerable marine ecosystems such as hydrothermal vents, or when destructive devices will be used. It must be stressed that the obligation to put the samples in openly accessible biorepositories should eventually minimise the need for subsequent sampling for the same MGR or in the same area, implementing the principle of avoidance of double sampling enshrined in the InterRidge Code of Conduct ${ }^{66}$ and the ABs CIESM Charter. ${ }^{67}$ One limitation, however, may be the fact that different types of research sometimes require different types of collection methods and storage. To this end, the effective coordination of the OPENs and of biorepositories will be required

64 GenBank * is the NIH genetic sequence database, an annotated collection of all publicly available DNA sequences. GenBank is part of the International Nucleotide Sequence Database Collaboration (INSDC), which comprises the DNA DataBank of Japan (DDBJ), the European Nucleotide Archive (ENA), and GenBank at NCBI. These three organizations exchange data on a daily basis. Available at https://www.ncbi.nlm.nih.gov/ genbank/; accessed 17 March 2017.

65 Available at https://www.insdc.org/policy; accessed 17 March 2017.

66 Available at https://www.interridge.org/node/16908; accessed 17 March 2017.

67 Available at http://www.ciesm.org/forums/index.php?post/2013/03/14/CIESM-Charter -on-ABS; accessed 17 March 2017. 
to ensure the dissemination of information regarding samples and their availability amongst the scientific community.

Another trigger for EIA could be the harvest of species that can, following interesting discoveries on their genetic material, be deemed necessary for the development of a product. For instance, Chris Battershill and his New Zealand colleagues collected several tons of the Lissodendoryx sponge after a careful environmental survey in order to provide the US National Cancer Institute with sufficient supplies of the bioactive compound halichondrin B for clinical testing against cancer. This research eventually led to eribulin, a simplified synthetic analogue of halichondrin Bcompound, Eribulin ${ }^{\mathrm{TM}}$, which has been approved for clinical use as an anticancer agent. A case like this should trigger not only an authorisation process through the EIA requirement, but also the addition of an access fee to the OPEN process, considering the administration needed for an EIA. Ventures: Sharing Conditions and Exceptions

Bearing in mind the main disparity between countries as previously explained, it must be stressed that promoting or facilitating access to ex situ and in silico MGR for researchers worldwide provides a significant and public benefit. Free or 'at cost' access to in situ resources is to be conditional on the creation or strengthening of already existing "common pools" 68 of MGR coming from ABNJ and the associated raw data. ${ }^{69}$ Facilitated in situ access, coupled with the sharing of ex situ MGR and in silico data, will ensure equal levels of opportunity in research to the scientific community worldwide, overcoming one of the main gaps in research capability between countries.

To this end, one must differentiate access from utilisation: access, the acquisition of samples or data, does not constitute utilisation. There is no direct and immediate commercial value at the access point, hence there should be no need for authorisation, and no discrimination, in this facilitated access procedure. No procedural distinction should be made between public and private entities, or between basic research and commercially driven research, as long as the users respect the set of conditions based on the OA principle and on benefit-sharing.

68 Broggiato et al. (n 20), at p. 181; Greiber (n 21), at p. 407-411; Wright et al. (n 21) at p. 556.

69 This would have to be delocalised as no single collection can do this. Using a virtual system can collate all the available data and perhaps even lead to reduction in the oversampling of certain deep-sea areas, such as the Mariana Trench. 
In practice, these conditions will need to be encoded into legal obligations: at the moment the OPEN notification is submitted the users sign clickwrap terms containing the obligations to share the raw data in public databases, such as GenBank, according to the principle of $\mathrm{OA}$, and to deposit any existing duplicates of the samples in public biorepositories. The terms also should contain an obligation to make payments to the biodiversity contribution fund in cases of commercialisation of a product derived later from the accessed resources, in case monetary benefit sharing are agreed upon by the ILBI. A further obligation could include the payment of an exclusivity fee in return for an embargo on the release of the samples and data into the public domain, for a period to be determined, potentially renewable upon payment of a further fee, in order to secure R\&D or potential commercial intent, regardless of whether such intent is known upstream or arises later in the process.

As a limitation to the obligation to share raw data and accessed materials, the grant of an initial embargo period should be left as an option for the users, to allow them to capitalise on their research material. The embargo period should be reasonable but fairly short, considering that only the raw data are to be released and not the detailed research results. It will nevertheless be possible to extend the embargo period by payment of an exclusivity fee. These possibilities should be clearly stated at the time of filling in the OPEN. The embargo period should secure biodiscovery investments and thereby future discoveries, start-ups, and innovative R\&D, but should not in any case free the user from its benefit-sharing obligations: the ultimate release of samples and raw data to the public domain, and the payment of monetary contributions when a product is eventually commercialised, if the latter is agreed upon by the ILBI.

\subsection{Benefit-sharing Obligations}

The first benefit to be shared under Mare Geneticum is enabling and facilitating access to MGR and associated data, thus empowering humankind to make the best of the last frontier that is the ABNJ. Scientific research produces benefits per se, including the better understanding of the marine environment, marine ecology and the oceanic system, and the improvement of the sustainable use of the oceans and its resources. Hence MSR represents a benefit for all that goes beyond the availability of any products made from $M G R,{ }^{70}$ even

70 T Greiber, 'Types of benefits and benefit sharing' in IUCN information papers for the intersessional workshop on marine genetic resources in ABNJ (IUCN Environmental Law Center, Bonn, 2013) 29-37, at p. 29. 
though some of these may make important contributions to public health, bioremediation or food security, and also produce global benefits. ${ }^{71}$

There is, however, no guarantee of monetary benefits arising out of the utilisation of MGR. ${ }^{72}$ In fact, only seven pharmaceutical products derived from marine organisms are currently on the market. Five of these are small molecule drugs discovered before 1990, all of which took more than fifteen years to develop into clinical products. By 1990, 5,800 small molecules of marine origin had been reported, meaning that just one compound for every 1,160 led to a commercial product. Given the long development timelines for pharmaceuticals, no compound discovered after the adoption of the СвD has reached the market yet. At the moment, twenty-eight marine natural products are in clinical trials and a further 250 are undergoing preclinical investigation. ${ }^{73}$ In addition, it must be stressed that, of the seven marine-derived products in use, six come from organisms found in the EEzs of coastal states. The seventh product, a highly purified polyunsaturated fatty acid (Omacor ${ }^{\circ} /$ Lovaza $^{\circ}$ ) used by patients at risk of heart attack, is derived from a range of fish species appearing both within and beyond national jurisdiction. Whereas the other substances are developed by chemical or biochemical processes, Omacor/ Lovaza requires the harvesting of fish in order to produce the product. One of the seven, Eribulin (trade name Halaven', produced by Eisai) required 25 years of development before reaching significant sales, Y29,3 billion in 2014, or USD $\$ 282$ million at the current conversion rate. ${ }^{74}$

Given the above, non-monetary benefits are considered the most practical and immediately valuable aspect of ABS, in particular because the chances of developing a commercial product are relatively slim. For this, OA databases are crucial. However, strengthening "common pools" not only requires the release of material, but also implies the need for global coordination, management, and institutional arrangements.

Even though the LOSC does not specifically provide for an ABS regime with regard to MGR in ABNJ, which will eventually be the role of the ILBI,

71 FO Glöckner, LJ Stal, RA Sandaa, JM Gasol, F O'Gara,F Hernandez, M Labrenz, E Stoica, MM Varela, A Bordalo, and P Pitta, 'Marine Microbial Diversity and its role in Ecosystem Functioning and Environmental Change' in JB Calewaert and N McDonough (eds), Marine Microbial Diversity and Its Role in Ecosystem Functioning and Environmental Change, Marine Board Position Paper 17 (Marine Board-ESF, Ostend, Belgium 2012) 17-41, at p. 25 .

72 Greiber (n 7o), at p. 32; Juniper (n 31), at pp. $19-20$.

73 Available at http://marinepharmacology.midwestern.edu/; accessed 18 January 2017.

74 Eisai Annual Report 2014, available at http://www.eisai.com/pdf/eannual/epdf2014an. pdf; accessed 18 January 2017. 
non-monetary benefit-sharing obligations applying to MSR in ABNJ are inherent in the Convention..$^{75}$ As a matter of fact, the scientific community already implements them as best practice (See infra). Accordingly, this aspect of our proposal is not inconsistent with LOSC.

\subsubsection{Non-monetary Benefits: the OA Principle as the Core Benefit}

Considering the above, non-monetary benefits will create direct, quasiimmediate benefits compared to monetary benefit-sharing. Moreover. they contribute to building capacity, creating opportunities, and promoting $R \& D$ in all countries. ${ }^{76}$ Non-monetary benefits include, among others, training of scientists, transfer of research results and scientific information, transfer of technology, and access to ex situ collections and in silico data. As most of these advantages emanate from research practice, the scientific community is one of the main stakeholders to be listened to when drafting a benefit-sharing regime for MGR in ABNJ. ${ }^{77}$

Part XIII of the LOSC conceptually deals with $\mathrm{MSR}^{78}$ occurring within national jurisdiction as well as in ABNJ, although without using this terminology. ${ }^{79}$ Part XIII contains clear obligations on non-monetary benefit-sharing arising from scientific research. ${ }^{80}$ In essence, it promotes international cooperation, and publication and dissemination of information and knowledge, especially in favour of developing countries. ${ }^{81}$ Article 244(1) sets the obligation for "States and competent international organizations [to] make available by publication and dissemination through appropriate channels [...] knowledge resulting from marine scientific research". Articles 143(3) (applicable to the Area) and 244(2) aim at strengthening autonomous MSR capabilities of less technologically developed states rather than by the mere transfer of technologies. ${ }^{82}$ The UN analysis of State practice indicates that data obtained through

\footnotetext{
75 Broggiato et al. (n 20), at p. 181. Greiber (n 69), at p. 44.

76 Glowka (n 35), at p. 9; Greiber (n 7o), at p. 32.

77 Vierros et al. (n 36$)$, at p. 212; Oldham (n 27), at p. 2.

78 Wright et al. (n 21), at p. 556 .

79 Greiber (n 70), at p. 35 .

8 Broggiato, (n 20), 176-185, at p. 182; Greiber (n 70), at p. 35 .

81 Article $242-244$ LOSC.

82 A Broggiato, T Dedeurwaerdere, F Batur ansd B Coolsaet, 'Introduction. Access and Benefit-Sharing and the Nagoya Protocol: the Confluence of Abiding Legal Doctrines' in B Coolsaet, F Batur, A Broggiato, J Pitseys, T Dedeurwaerdere (eds), Implementing the Nagoya Protocol-Comparing Access and Benefit-sharing Regimes in Europe (Brill/ Martinus Nijhoff Publishers, Leiden, 2015) 1-29, at p. 11.
} 
MSR, particularly from $A B N J$, are effectively shared via international data repositories such as Ов Is, as well as via publication in international journals. 83

These provisions constitute the legal basis for further development of a comprehensive and coherent non-monetary benefit-sharing scheme for MGR in ABNJ. To this extent, the OA principle at the basis of the Mare Geneticum governance is consistent with both these Losc obligations and the current scientific practice and values.

Many scientific codes of conduct and guidelines ${ }^{84}$ are already raising awareness and building up best practice in the MSR community in terms of sharing samples, data and research results, as well as strengthening capacity building and training in developing countries. ${ }^{85}$ Various examples include the already existing gene banks, digital databanks, scientific journals and patent pools, ${ }^{86}$ but also the common practice of joint research programmes. For instance, the Intergovernmental Oceanographic Commission of UNESCO (IOC-UNESCO) ${ }^{87}$ widely promotes international cooperation in MSR, capacity building, technology transfer and data-sharing. The IOC collects, analyses and publishes information from states on practices in MSR and technology transfer. ${ }^{88}$ It has published guidelines for states on the transfer of marine technology, ${ }^{89}$ and has established a capacity-building development programme to strengthen MSR. It plays a role in international cooperation projects such as the International Oceanographic Data and Information Exchange (IODE), which facilitates

83 United Nations Division for Ocean Affairs and the Law of the Sea-Office of Legal Affairs, Marine Scientific Research: A Revised Guide to the Implementation of the Relevant Provisions of the United Nations Convention on the Law of the Sea (United Nations, New York, 2010) para 116.

84 See for example the InterRidge statement of commitment to responsible research practices at deep-sea hydrothermal vents; available at https://www.interridge.org/ IRStatement, accessed 18 January 2017; and the ABS CIESM Charter, supra (n 67).

85 Broggiato (n 20), at pp. $176-185$.

86 Patent pools are consortia of entities agreeing to cross-license patents relating to a particular technology in order to save time and money, to mitigate patent-related risks, and to create collective benefits.

87 IOC is a competent international organization under the UN Convention on the Law of the Sea for Marine Scientific Research under Part XIII and Capacity Development (CD) and Transfer of Marine Technology (тмт) under Part XIV. The IOC is the primary international organization responsible for marine science in the UN system, as also recognized by Losc (Annex 8 Article 2).

88 EJ Tirpak, Practices of States in the Fields of Marine Scientific Research and Transfer of Marine Technology: An Update of the 2005 Analysis of Member State Responses to Questionnaire No.3, UN Doc. IOC/ABE-LOS VIII/8 (19 March 2008).

89 Intergovernmental Oceanographic Commission, IOC Criteria and Guidelines on the Transfer of Marine Technology, IOC Information Document, 1203 (UNESCO, Paris, 2005). 
international cooperation on data format standards to harmonise the use of data between states.

In 1996, leaders of the scientific community advocated the immediate release of DNA sequence data in public databases in the Bermuda Principles. ${ }^{90}$ In 2007, the Organization for Economic Cooperation and Development (OECD) recommended wider and open sharing of data from public funding, ${ }^{91}$ followed by the European Commission's policy instructions to Member States to "promote the broad dissemination of knowledge created with public funds, by taking steps to encourage open access to research results, while enabling, where appropriate, the related intellectual property to be protected". ${ }^{92}$ From there national policies blossomed around the globe, in particular in the host countries of the main funding agencies that currently finance ABNJ research: the European Union (EU), the United States (US), China and Germany. ${ }^{93}$

What all these data policies have in common is the implementation of the OA approach, albeit to different extents. The National Science Foundation of the US adopted the Sample and Data Policy of the Division of Ocean Sciences in $2011 .{ }^{94}$ This requires the Principal Investigator working under its funding "to submit at no more than incremental cost and within a reasonable time frame (but no later than two (2) years after the data are collected), the primary data, samples, physical collections and other supporting materials created or gathered in the course of work under NSF/OCE grants". It further requires submission of sequence data to a publicly accessible data repository. The EU published a Recommendation on access to and preservation of scientific information in $2012^{95}$ encouraging all EU Member States to put publicly-funded research results in the public domain in order to strengthen science and the

9o For a summary of the principles agreed at the first international strategy meeting on human genome sequencing (commonly referred to as Bermuda Principles of 1996), see http://www.ornl.gov/sci/techresources/Human_Genome/research/bermuda.shtml, accessed 17 March 2017. For a historical analysis of the principles, see Eliot Marshall, 'Bermuda Rules: Community Spirit, with Teeth' (2001) 291 (5507) Science 1192.

$91 \mathrm{OECD}, \mathrm{OECD}$ Principles and Guidelines for Access to Research Data from Public Funding, http://www.oecd.org/science/scienceandtechnologypolicy/38500813.pdf Accessed 17 March 2017.

92 EC recommendation C/2008/1329 of 10 April 2008, http://eurlex.europa.eu/LexUriServ/ LexUriServ.do?uri=CELEX:32008Ho416:EN:NOT; COMMISSION RECOMMENDATION of 17 July 2012 on access to and preservation of scientific information $(2012 / 417 / \mathrm{EU})$ Official Journal of the European Union L 194/39 21/07/2012.

93 See Oldham et al. (n 27), at p. 77.

94 Available at https://www.nsf.gov/pubs/2011/nsfino6o/nsfino6o.pdf Accessed 17 March 2017.

95 Commission Recommendation of 17.7.2012 on access to and preservation of scientific information. C(2012) 4890 final. Available at https://ec.europa.eu/research/science 
knowledge-based economy. In 2014 the National Natural Science Foundation of China (NNSFC), one of the country's major basic-science funding agencies, and the Chinese Academy of Sciences (CAS) announced that researchers they support should deposit their papers into online repositories and make them publicly accessible within 12 months of publication. In 2015, the Deutsche Forschungsgemeinschaft (DFG) adopted Guidelines on the Handling of Research Data, calling for the long-term archiving of research data and OA to it. ${ }^{96}$

Although OA to sample material is less advanced, there is a global movement towards enabling the long-term maintenance of valuable biological, chemical and other materials resulting from research activities. In the field of deep-sea research, the scientific community advocates increased sharing of such samples and for research grants to include a budget for curation and longterm care. Samples arising from MSR carried out in ABNJ can often be accessed through international networks of collections. For example, the InterRidge statement of commitment to responsible research practice notes that the network is building open databases on available biological samples preserved in laboratories and museums around the globe, as an available resource and to minimise repeated sampling. ${ }^{97}$

In addition, many journals currently require unique material included in publications to be made available. The journal Nature's policy states that:

A condition of publication in a Nature journal is that authors are required to make unique materials promptly available to others without undue qualifications. It is acceptable to request reasonable payment to cover costs of distribution and reagents may be made available via commercial or non-commercial third party providers. ${ }^{98}$

Such a strong statement from a top international peer-reviewed journal sends a message that sharing of material is essential for a productive global research enterprise, although compliance with this requirement may still need

-society/document_library/pdf_o6/recommendation-access-and-preservation-scientific -information_en.pdf; accessed 17 March 2017.

96 Available at http://www.dfg.de/download/pdf/foerderung/antragstellung/forschungs daten/guidelines_research_data.pdf; accessed 17 March 2017.

97 See the InterRidge Code of Conduct (n 68).

98 Available at http://www.nature.com/authors/policies/availability.html; accessed 18 January 2017. 
to improve. ${ }^{99}$ This trend has resulted in best practice in open science, technological advances and the ever-growing practice of digitalisation of genetic data and other information, which has enabled more global accessibility than ever before. ${ }^{100}$ Therefore, enabling and increasing access to relevant scientific data, publications and software to analyse these data is undoubtedly an important component of non-monetary benefit sharing. ${ }^{101}$ However, the moderate optimism brought by new opportunities thereby created cannot obscure the reality faced by some researchers and users from developing countries, whose institutions do not always have the necessary licenses for access to journals, or the necessary internet access and bandwidth and other necessary resources. In this respect, the biodiversity contribution fund to be established by the ILBI could assist those in need of better access.

\subsubsection{Monetary Benefit-sharing}

The present section deals with the potential obligation to require monetary payments at different stages of the research pipeline. There could be two milestones at which monetary payments may be foreseen.

1. The OPEN entails payment of an exclusivity fee early in the biodiscovery process, when the user wants to extend the embargo period on releasing the MGR collected in ABNJ to the public domain. When the exclusivity option is exercised, payment of the exclusivity fee is compulsory and should be transferred to the biodiversity contribution fund to be established by the ILBI. The exclusivity fee's amount could be determined by a sliding scale, depending on various factors: the duration of the extension period, the MGR concerned by the embargo, the level of research funding employed to date, and the user's financial capacity.

2. If the ILBI would require monetary benefits linked to the utilisation of the genetic resource as such, we suggest this second payment step to be triggered by the commercialisation of a product developed on the basis of MGR from ABNJ. This form of royalty should be paid to the same international fund set up by the ILBI to manage exclusivity fees. The percentage of revenue to be shared should be predetermined and fixed, possibly by consultation with representative organisations and stakeholders of several biotechnology sectors, in order to provide for legal

99 D Cyranoski, 'Research materials: Share and share alike?' (2002) 420 Nature 602-604, at p. 604 .

100 GM Garrity, LM Thompson, DW Ussery, N Paskin, D Baker, P Desmeth, DE Schindel and PS Ong, Study on the Identification, Tracking and Monitoring of Genetic Resources, UN doc. UNEP/CBD/WG-ABS/7/INF/2, of 2 March 2009, p. 19.

101 Greiber ( $\mathrm{n} 7 \mathrm{o})$, at p. 35 . 
certainty, predictability and equity amongst players. It should also be consistent with the market levels payable under ABs systems already in place within national jurisdictions (e.g., Brazil) and under development at regional levels, to avoid creating any perverse incentives.

Considering that it may take over 20 years to release a product onto the market, having the possibility to pay an exclusivity fee at an early stage of the research not only guarantees continuous investments in blue biodiscovery, but also secures early incoming monetary resources for the ILBI contribution fund.

With these governance principles, Mare Geneticum seeks to achieve the fair and equitable sharing of the benefits arising out of utilisation of MGR coming from $A B N J$, and to enhance MSR and enable biodiscovery worldwide for the benefit of humankind. However, promoting fundamental research through $\mathrm{OA}$ whilst allowing users to take research results to the level of application and commercialisation of the biodiscovery pipeline will be a difficult balance to achieve.

\subsection{Enforcement and Compliance: Centralised Tracking System}

Ensuring compliance with and enforcement of benefit-sharing obligations is not an easy task, especially within a multilateral context. To this end, the OPEN registry would provide a centralised system where monitoring can be based on reporting and updating obligations. At the end of a non-commercial research project or at the moment of commercialisation of a product developed on the basis of MGR coming from ABNJ, a second OPEN notification could be envisaged and would need to be linked to the first one. An alternative could be additional information and potentially additional conditions (e.g., exclusivity) to be annexed to the pre-existing OPEN.

Effective compliance starts with the obligation to report activities to the institution that will be mandated or established by the ILBI for managing access to MGR and the OPEN registry, similarly to the International Seabed Authority's reporting requirements imposed on seabed mining contractors. ${ }^{102}$ There would be an obligation to update, either on a regular basis (e.g., annually) or upon reaching certain milestones in the MGR lifetime, but should at the very least occur at every permanent subsequent transfer to collections or to different users, and when the type or the intent of the utilisation changes (e.g., when commercial intent arises). Using the OPEN as the central tracking system will ensure the smooth and effective monitoring of MGR utilisation. The obligation to update or report will first be imposed upon the responsible person of a

102 LOSC, Annex III, Article 17(1)(b). 
research project accessing MGR in situ, but when signing the OPEN clickwrap agreement, it should also be binding for any subsequent user accessing MG R ex situ, or data in silico when possible. In other words, because it is quite often the case that multiple users conduct research on the same MGR and that thirdparty transfer is common practice in biodiscovery ventures, ${ }^{103}$ the obligation should be tied to the MGR through the OPEN and its unique identifier, and not to the primary user only. Subsequent users can easily become subject to the OPEN conditions applicable when signing a material transfer agreement with peers or with a biorepository, containing as such a viral licence.

Low impact, cost-effective monitoring is advisable. Trust should be placed in researchers to report sample collection along with findings and transfers. Ocean scientists must be meticulous about recording when and where samples are collected in situ because it is an indispensable part of research methodology and protocols, hence it is unlikely to put any additional burden on researchers. ${ }^{104}$ Moreover, as previously mentioned, most funding agencies and scientific journal editors require researchers to deposit genetic and proteomic data in publicly accessible archives where they are openly accessible. Reporting standards should be simple, consistent and interoperable.

Further along the research chain, potential R\&D users of MGR coming from ABNJ should submit a new notification when a commercially oriented project begins, considering that such a change of intent might trigger the need for additional conditions of use other than just an embargo period on the public release of said MGR and associated data. In particular, there might be intellectual property rights to take into account, as well as payment requirements arising from the monetary benefit-sharing provisions of the ILBI. This new notification could either be in the form of an annex to the MGR'S OPEN, or as a second OPEN that should be linked to the first one.

With today's powerful tools such as computer programmes and the Internet, setting up a centralised tracking system is not only possible but also relatively simple to establish and operate. This tracking format has been set up by the 2015 Brazilian legislation on access to and use of its genetic resources, ${ }^{105}$ whereby users have to submit similar information to an ABS registry. However, its effectiveness cannot be evaluated, as it is not yet operational.

103 M Jaspars, D De Pascale, JH Andersen, F Reyes, AD Crawford and A Ianora, 'The Marine Biodiscovery Pipeline and Ocean Medicines of Tomorrow' (2016) 96(1) Journal of the Marine Biological Association of the United Kingdom 151-158.

104 Vierros et al. (n 36), at p. 212.

105 Brazilian Biodiversity Law, Federal Act No. 13.123/2015, 20 May 2015; Decree No. 8.772/2016, 11 May 2016. 
The IOC-UNESCO could easily support the ILBI's implementation with regard to the OPEN mechanism, by providing:

(i) A global data-sharing platform and data clearing-house mechanism for marine taxonomic, genetic, biodiversity and associated data in all ocean basins, including ABNJ;

(ii) A mechanism for international cooperation in MSR, coordination in global ocean observation, and development of standards, manuals and guidelines and codes of conduct in MSR and data-sharing protocols;

(iii) A global network of regional centres to enhance capacity, by training the next generation of scientists and area managers in applying international standardsandbestpractices. ${ }^{106}$

Although States are responsible for the implementation of international treaties, the centralised system for OPENs would alleviate the legislative and administrative means to be deployed in order to ensure compliance. Indeed, instead of managing ABNJ material and data through national registries to be coordinated at a global level, States would merely have to ensure that users comply with adequate and effective reporting. The failure to report or comply with the OPEN conditions, when observed by the mandated international organisation, or by funding agencies when possible, should be notified to the relevant State, and be subject to sufficiently and proportionally discouraging penalties in order to ensure the equal compliance of public and private research organisations. Compliance mechanisms will be the responsibility of State parties to the ILBI, and should serve as incentives to respect the Mare Geneticum governance established by it. Any international organisation put in place by the ILBI should coordinate and manage the OPEN mechanism with State parties, leaving enforcement to the States. To this end, there will be an important need to set globally accepted, and harmonised, minimum standards of compliance. It is thus within the hands of States, as both international law makers and subjects, to draft an ILBI reflecting the balanced regime necessary to efficiently share the benefits of MGR without impeding or slowing down research.

106 IOC-Unesco 'Ioc Potential Contribution To A New International Instrument Under UnClos On The Conservation And Sustainable Use Of Marine Biological Diversity Of Areas Beyond National Jurisdiction', Information Document IOC/INF-1338, Paris, 17 May 2016. Available athttp://ioc-unesco.org/index.php?option=com_oe\&task=viewDocument Record\&docID=17286; accessed 18 January 2017. 
The governing principles and implementing mechanisms put forward in this article are intended to lay the basis for a new governance regime in the high and the deep seas that are, by nature and by law, international. Based on the idea that the utilisation of MGR should benefit the world as a whole, notwithstanding the intellectual property rights that may arise from associated discoveries, Mare Geneticum's approach is about adequate regulation for better sharing, in a distant echo of Grotius:

Now, as there are some things which every man enjoys in common with all other men, and there are other things which are distinctly his and belong to no one else, just so has nature willed that some of the things which she has created for the use of mankind remain common to all, and that others through the industry and labor of each man become his own. ${ }^{107}$

The international community has engaged in the process of developing an implementing agreement to the LOSC in ABNJ, the ILBI. It is going to be their task to draft a realistic and balanced system based on sound foundations. During the Preparatory Committee's sessions for an ILBI, several States have called for open access to research data, samples and knowledge, as well as the need for a data-sharing and clearing house facility. Although a number of databases and biorepositories already exist, what will be needed is a coordinated tracking system, such as the unique identifier of an OPEN record for MGR samples and data from $\mathrm{ABNJ}$.

The new ILBI should adopt a simplified monetary benefit-sharing system in order to promote biodiscovery initiatives rather than to deter them, and to avoid implementation struggles, as may be seen with the LOsC Part XI regime on seabed mining. ${ }^{108}$ Above all, the ILBI should emphasize and strengthen non-monetary benefit-sharing for the advancement of science and nature conservation through, inter alia:

- Open access to raw data and samples;

- Enhanced international research coordination and cooperation;

- Targeted training and sharing of expertise, methodology, guidelines and best practices;

- Standardised data management, taxonomy and species identification;

107 Grotius (n 1), at p. 2.

108 J-S Fritz, 'Deep Sea Anarchy: Mining at the Frontiers of International Law' (2015) 30 The International Journal of Marine and Coastal Law 445-476. 
- Marine spatial planning in ABNJ, including protected areas;

- Ecosystem-based management;

- Development of marine conservation policies.

Indeed, because Mare Geneticum is not a stand-alone approach but part of a four-component package, sharing the benefits arising out of MGR in ABNJ should also mean attributing such benefits to the designation and management of marine protected areas, the systematisation of EIA processes, and the transfer of technology. Notwithstanding the fact that the world has a lot to gain from healthy and sustainably managed oceans, the Losc Preamble is here to recall that the spirit and purpose of the Convention as a whole is to "promote the peaceful uses of the seas and oceans, the equitable and efficient utilisation of their resources, the conservation of their living resources, and the study, protection and preservation of the marine environment". 